\title{
Reflection on Promoting Northeast Asian Culture Blending English Teaching in the Context of "One Belt and One Road"
}

\author{
*Bing $\mathrm{He}$ \\ School of foreign language, Dalian Jiaotong University, DaLian, China \\ *Corresponding author e-mail: rachelhe2008@163.com
}

\begin{abstract}
The high degree of integration of regional culture and the continuous support of talents are prerequisites for achieving regional common prosperity. The proposal of "one belt and one road" initiative has provided unprecedented opportunities for scientific research cooperation, talent exchange and regional culture education among universities in Northeast Asia. It has become the general trend to build a "community of common destiny" through regional cooperation in Northeast Asia. Cultural identity can be an effective means to promote in-depth cooperation in Northeast Asia. Taking the regional culture and education of colleges and universities as the breakthrough point, the cultural and educational community of colleges and universities in Northeast Asia should be constructed to actively serve Northeast Asia. In view of these problems, College English teaching needs to help students to establish innovative awareness. Teachers should update educational concepts, innovate teaching models, build courses related to the common prosperity and development of College English and Northeast Asia. Furthermore, teachers should establish and improve the multi evaluation system, strengthen practical teaching, and enhance the cultural identity of College Students, which will be conducive to further expanding consensus and understanding, and then effectively promote the common prosperity of Northeast Asia.
\end{abstract}

Keywords: Northeast Asia, cultural identity, "one belt and one road”, universities, English teaching

\section{INTRODUCTION}

Since the eighteen Party's Congress, the Party Central Committee with Comrade Xi Jinping at its core has put forward the "one belt and one road" initiative in a strategically advantageous position in line with the complicated changes in the international situation and the regional situation and the new situation of building socialism with Chinese characteristics. This also means that the political and economic exchanges between China and other countries, especially the Northeast Asian countries, will become increasingly frequent, and the cultural exchanges and cooperation between China and other countries will continue to deepen. At the same time, it also provides good external conditions for cultural cooperation between China and neighbouring countries in Northeast Asia. [1] Peace and development have become a new era of development with a new theme in the world. Win-win cooperation has become the core connotation of international relations. Regional cooperation among countries in Northeast Asia needs to be further strengthened. As an initiator of this problem the "one belt and one road" initiative, how to innovate the development mode and realize the deep integration of cultures in Northeast Asian countries? How to achieve the breakthrough in the common development of the Northeast Asian region in the "one belt and one road" initiative is an important topic that we must seriously study and solve.

\section{THE CURRENT SITUATION OF CULTURAL EXCHANGE BETWEEN CHINA AND NOTHEAST ASIAN COUNTRIES}

Cultural exchange includes the following three aspects: the cultural exchange and information dissemination activities around the Han nationality and other ethnic minorities; the cultural exchange and information dissemination activities around the Chinese nation and other ethnic groups and races; the cultural exchange and information dissemination between Chinese culture and Christian culture, Islamic culture, Hindu culture and other major cultures in the world as representatives Activities. The cultural exchange in Northeast Asia is not the interval and block of the strong wall and the mutual barrier, but the state of fan-shaped 
mutual penetration and integration. With the emergence of the international global village, although each country does its own thing, the cultural exchange will not be completely separated due to the barrier of the border, which also provides conditions for the strategic exploration of cultural peripheral communication.

\section{STRATEGIC ORIENTATION OF CULTURAL COMMUNICATION AROUND CHINA AROUND CHINA NORTHEAST ASIA}

From the perspective of cultural elements, culture is a value and meaning system shared by a group or society, which is composed of three important factors: symbol, meaning and values, norm and material culture. [2] The goals and methods of strategic communication coincide with the mobility of culture, and provide theoretical direction and macro planning for it. From the perspective of regional communication, international communication and cross-cultural communication under the framework of China Northeast Asia location, this paper considers how to plan the strategy of surrounding cultural communication facing Northeast Asia. In the process of cultural integration in Northeast Asia, we can see the signs of high interdependence, the sense of common destiny in the context of regional integration and globalization, the growing common norms and the self-restraint of big powers. Through cultural communication activities and peripheral communication activities including other elements, we will jointly build a traditional and modern image of China with cultural diversity and inclusiveness, so as to further improve and enhance China's stereotype in the surrounding countries of Northeast Asia, and enable countries to better accept China's concept. Therefore, when facing the Northeast Asia, cross-cultural elements are not only the basis of communication activities, but also a more profound strategic layout, which needs to be highlighted in the future strategic positioning.

\subsection{Turn area "sector" into peripheral "coil"}

As a concept of communication, the biggest difference between region and periphery lies in that the former refers to agglomerations, while the latter refers to coils. "Lines can be thick or thin, loops can be large or small"; the former can refer to domestic or international, but sometimes it can only refer to domestic, rather than international, while the latter can refer to both domestic and international. [3] From the current practice of China around Northeast Asia, it has not fully expanded the "fan", trapped in the regional thinking prison, which is exactly the circle that the cultural communication around Northeast Asia needs to open at the strategic level. The surrounding "coil" is constantly changing. In the elastic change of its thickness and size, it promotes the cultural exchange and interaction between regions, and thus shakes the social, economic, trade, culture, art and other aspects. Therefore, it is necessary to adjust and upgrade the variables among these regions from a strategic perspective to integrate the cultural elements among the regions in Northeast Asia. It should be admitted that the dissemination of internal culture in different regions is a precursor to the dissemination of Northeast Asian culture. If the cultural exchanges in these areas are ignored, the spread of the surrounding culture cannot be carried out; however, the discussion of the ways and means of restricting the spread of the surrounding culture in the small area cannot achieve the goal of building a larger scale under the "one belt and one road", nor can it adapt to it. Therefore, China's communication around Northeast Asia should first strengthen the links among the three north-eastern provinces, Inner Mongolia Autonomous Region and other regions, so as to lay a solid foundation for promoting the goal of higher-level cultural communication.

\subsection{Breaking through the inherent thinking of traditional international communication}

Generally speaking, China's communication pattern of surrounding countries, including Northeast Asia, still hasn't got rid of the communication pattern with mass media as the body and propaganda reports as the use. There are various audiences living around Northeast Asia with various social systems and ideological forms, so both the reception pattern and the reception psychology should be re-evaluated. Different from the single subject, narrow scope, homogenization and fuzziness of content and means of international communication, peripheral communication is more rich and diverse in subject, scope, content and means. The main body of international communication is the state and the media, and the scope is all countries and regions outside the main body of communication. The content and means are universal sexual communication without distance or difference with the help of industrialized and popular mass media. The main body of peripheral communication includes local governments, enterprises, schools, individuals and even objects outside the state and the media, and the scope includes The related countries, regions and nationalities on both sides of the border, including the main body of communication, are relatively close to each other in content and means, and the content and means vary with the object. [4] At present, China's communication around Northeast Asia is based on the central government and national radio and television as the core, the regional radio and television as the extension, and the official network media as the supplementary main body; the exposition, cultural festival and academic forum held by local governments, enterprise organizations and academic institutions as the public diplomacy means; and the dissemination of China's national concept, customs and folk life as the internal The communication system of capacity. From the perspective of strategic communication, these elements should be "piecemeal" under reasonable 
planning, and play their functions in the communication around Northeast Asia on the basis of highlighting their respective advantages.

\subsection{Fully optimize and upgrade cross-cultural communication elements}

Whether it's peripheral communication or cross-cultural communication, the main factor of them is culture. But in communication activities, culture as a paradigm is quite different. Cross cultural communication emphasizes cultural differences, and culture is the most important element. Its purpose is to enhance understanding, promote communication, seek assimilation and rational coexistence. While peripheral communication emphasizes the same and similar culture, culture is only one of its communication activities, and its purpose is to make good neighbourhoods, officials communicate with people, increase communication, and help each other. [5] The great social differences and complex ethnic levels of the countries in Northeast Asia are the challenges that China is facing in its communication to Northeast Asia, but they are also rare opportunities in the special historical period. In the long run, China is facing the communication practice of Northeast Asia through cross-cultural communication mirror, and emphasizes "transformation" in more discourse modes. From the perspective of cultural strategy, it is the cross-cultural elements that build the foundation of peripheral communication. The important element of culture can be linked with economic, political and other communication behaviours, and promote each other. Through cultural communication activities and peripheral communication activities including other elements, we can jointly build a traditional and modern image of China with cultural diversity and inclusiveness, so as to further improve and enhance the stereotype of China in the surrounding countries of Northeast Asia, and make countries better accept the Chinese philosophy Read. Therefore, when facing the Northeast Asia, the crosscultural elements are not only the basis of communication activities, but also a more profound strategic layout, which needs to be highlighted in the future strategic positioning.

\section{THE CURRENT SITUATION OF ENGLISH TEACHING FOR CULTURAL INTEGRATION AROUND NORTHEAST ASIA}

From the school point of view, many school educators are limited to the knowledge of English, ignoring the important role of cultural education and the cultivation of students' quality and ability. Teachers' teaching quality is often measured by students' test scores, and even college English test scores are linked with employment certificates. From the point of view of the current national policy, it is unreasonable and unscientific to evaluate teachers' teaching quality only by measuring students' examination level. [6] Students should not start from strategic optimization in order to get graduation certificate through examination. It is a necessary task to cultivate specialized and compound talents with outstanding foreign language ability, solid political ideology and broad communication vision in Colleges and universities.

College English course is a compulsory basic course for college students, which is of great significance to cultivate students' foreign language ability, humanistic quality and application skills. Under the background of economic globalization, higher requirements have been put forward for College English teaching, which has gradually changed from academic and research oriented to application oriented. Especially under the background that the country pays more and more attention to the international cooperation and development, colleges and universities should combine college English teaching with innovation and entrepreneurship organically, develop cooperatively, and jointly cultivate a group of compound talents useful to the society.

\section{A GENERAL PLAN OF COLLEGE STUDENTS' ENGLISH TEACHING FOR THE PURPOSE OF CULTURAL BLENDING IN NORTHEAST ASIA}

The ultimate goal of promoting the education of cultural integration lies in the students. Only when the students accept the concept of cultural collision and integration and dare to practice, can they say that the education has a practical effect. [7] Therefore, teachers should take the concept of cultural integration of Northeast Asia as the carrier through their own classroom teaching and the professional teaching of College English knowledge, so as to cultivate the cultural communication awareness of college students. Encourage students to participate in various cultural exchange activities and College English competitions inside and outside the University, so as to improve their ability of fast learning, actively participate in various practical activities, and exercise their skills. The consciousness of innovation and entrepreneurship is cultivated in the practice of innovation and entrepreneurship.

At the same time, the university should establish and improve the diversified evaluation system of College English, including diagnostic evaluation, formative evaluation and summative evaluation. This multiple assessment system can well quantify the knowledge, skills and attitudes of students, and can also quantify the whole college English of students

\section{CONCLUSION}

As a product of the unique inclusiveness, continuity and expression of ethnic ideas in the process of the historical development of human society, culture has opened up a new vision of human development for promoting regional 
integration and strengthening regional exchanges. With the development trend of economic globalization and the increasingly frequent communication between social existence and ideology, the blending of common historical roots and the deepening of positive regional cooperation among Northeast Asian countries, even though the negative factors of history and reality doomed the twists and turns of the Northeast Asian regional cultural identity road. However, the dilemma is not desperate as long as we hold the good opportunity of cultural integration, giving full play to the strong tension of cultural identity, eliminating disputes, seeking common ground while reserving differences. Therefore, if we work together, building a prosperous era of "a community of shared destiny in Northeast Asia" is just around the corner.

\section{REFERENCES}

[1] National development and Reform Commission, Ministry of foreign affairs and Ministry of Commerce: vision and action to promote the joint construction of the Silk Road Economic Belt and the 21st century Maritime Silk Road, people's daily, 4th Edition, March 29, 2015.

[2] Bi Yantao, Wang Jinling. Strategic Communication [J]. Journal of Hainan Normal University, 2011 (5)

[3] Qin Yaqing, Wei Ling. Socialization of structure, process and power: cooperation between China and East Asia. World economy and politics, 2007 (3)

[4] Liang ronghua, Zhang Dewei: new trends of education reform and development in Northeast Asian countries -- a summary of "International Seminar on education reform and development in Northeast Asia", foreign education research, No. 7, 2011

[5] Knight, J: The Palgrave Handbook of Asia Pacific Higher Education. New York: Palgrave Macmillan. 2016.

[6] http: //www.moe.edu.cn/srcsite/A20/s7068/201608/t2016081 1_274679.html.

[7] Sheng Zhengfa, Lei Mingqiang: the development of higher education in Northeast Asia Trend and university cooperation -- Northeast Asia branch of the World Federation of University Presidents Summary of 2010 conference, global education outlook, 2011, issue 2. 